\title{
CHANGES IN GENE EXPRESSION OF LACTATE CARRIERS (MCT1 AND CD147) IN CARDIAC MUSCLE OF DIABETIC MALE RATS: THE EFFECT OF DICHLOROACETATE AND ENDURANCE TRAINING
}

\author{
H. REZAEINASAB ${ }^{1 凶}$, A. HABIBI ${ }^{1}$, M. NIKBAKHT $T^{1}$, M. RASHNO ${ }^{2,3}$, S. SHAKERIAN ${ }^{1}$ \\ ${ }^{1}$ Department of Exercise Physiology, Faculty of Sport Sciences, \\ Shahid Chamran University of Ahvaz, Ahvaz, Iran; \\ ${ }^{2}$ Department of Immunology, Faculty of Medicine, \\ Ahvaz Jundishapur University of Medical Sciences, Ahvaz, Iran; \\ ${ }^{3}$ Department of Cellular and Molecular Research Center, \\ Ahvaz Jundishapur University of Medical Sciences, Ahvaz, Iran. \\ 凶e-mail: hamed.rezaei2020@gmail.com
}

Received: 23 March 2020; Accepted: 25 June 2020

Lactate accumulation can activate the pathways of mitochondrial biogenesis in the heart muscle. The purpose of this study was to investigate the effects of Pyruvate Dehydrogenase Kinase 4 (PDK4) inhibition and endurance training on the gene expression of lactate carriers (MCT1 and CD147) in the cardiac muscle of STZ-diabetic rats. In this experimental study, 64 male Wistar rats were selected and randomly divided into eight groups after induction of diabetes with streptozotocin (STZ). The endurance training protocol was performed on a treadmill for 6 weeks. Intraperitoneal injection of DCA of $50 \mathrm{mg} / \mathrm{kg}$ body weight was used for the inhibition of PDK4 in the myocardium. Gene expression were measured using real-time PCR. The two-way ANOVA test was used to analyze the data. The results of the study showed that after endurance training, the expression of MCT1, PDK4, and CD147 genes increased significantly in line with each other $(P<0.05)$, and by inhibition of PDK4 in the heart muscle, the expression of MCT1 and CD147 genes in the endurance training group + diabetes $+D C A$ and in the diabetes group $+D C A$ decreased significantly $(P<0.05)$. According to the results of this study, it can be concluded that the repeated accumulation of lactate caused by exercise training in diabetic patients decrease through mitochondrial adaptation by DCA injection and subsequently oxidative stress can be reduced in cardiac tissue of diabetic patients and heart efficacy can be increased.

Ke y wo rd s: gene expression, diabetes, lactate, endurance training, DCA.

$\mathrm{P}$ atients with diabetes are at risk of death for cardiovascular diseases [1, 2]. It has earlier been shown that the causes of death for chronic heart failure in diabetic patients are approximately twice as high as those patients without diabetes [1]. The term cardiomyopathy has recently been used to diagnose cardiovascular dysfunction in diabetics [3]. Physical activity affects many physiological systems in the body, including the structure and function of the heart muscle [4]. Research has shown that the heart muscle is adapted structurally and efficiently to the type of stimulus provided by physical activity (endurance or strength) (5). Lactate can be oxidized into oxidative muscle and cardiac muscle, converted to glycogen in fast contractions, or converted to glucose in the liver and kidney through the process of gluconeogenesis and returned to the bloodstream. So, the substrate is constantly exchanging in different cells and between different tissues [6]. This transfer is carried out among different $\mathrm{pH}$-dependent tissues and in the manner of transporting the hydrogen ion via transporter monocarboxylates (MCTs) [7, 8]. MCT1 and MCT4 are the isoforms that play the most important role in regulating lactate flow through the cell membrane, and it is expressed in cardiac muscle and skeletal

(C) 2020 Rezaeinasab H. et al. This is an open-access article distributed under the terms of the Creative Commons Attribution License, which permits unrestricted use, distribution, and reproduction in any medium, provided the original author and source are credited. 
muscles of humans and animals with a specificity of movement and different locations [9]. The studies have shown that physical activity [10], electrical stimulation [11), and hypoxia have a significant effect on the expression of MCT1 in the heart muscle [12]. MCT1 is mainly expressed through endurance training and is related to the oxidative capacity of the muscle [6]. The role of CD147, a glycoprotein, is more prominent in investigating the mechanisms that are effective in expressing lactate transporter. In confirmation of this, cell culture studies have shown that CD147 plays an important role in the expression of normal MCT1 on the cell surface membrane [13]. Also, the role of CD147 in the delivery of MCT1 to the surface of the membrane has been confirmed in previous studies [14]. On the other hand, in rats that the $C D 147$ gene has been muted, the expression of this transmitter has been reduced in spite of the presence of MCT1 mRNA [13]. On the other hand, the heart demands very high energy and basically has no energy reserves. Therefore, it must continuously rebuild the high levels of energy or adenosine triphosphate (ATP) at high speeds to maintain contractile function and ion hemostasis [15]. Most ATP in mitochondria which are produced by oxidative phosphorylation and fatty acids and carbohydrates are primary energy substrates, with fatty acids representing respectively 50-70 percent of ATP production [15]. But the diabetic heart cannot completely use glucose due to insulin deficiency and therefore it needs to use almost exclusively fatty acids for energy sources $[16,17]$. Previous research has shown that the decrease of glucose was done by DCA stimulation in diabetic rats; it was also associated with stimulation of glucose oxidation and inhibition of fatty acids oxidation in peripheral tissues of diabetic rats [18]. DCA and some of its derivatives by activating the PDC, which is a multifunctional set in the mitochondrial matrix, and has the role of the gatekeeper in the association of cytoplasmic glycolysis with the tricarboxylic acid (TCA) cycle and oxidative phosphorylation; it is along with regulating diabetes and other conditions that increase beta-oxidation of fatty acids (such as endurance training) [19]. Also, the results of research by Tobina et al. emphasize on the hypothesis that lactate accumulation during exercise is associated with mitochondrial biogenesis of exerciseinduced [20]. However, in spite of studies on lactate carriers and its effects on the metabolism of diabetic patients as well as DCA use, some research findings are still highly controversial; and no research has done to investigate the effect of DCA's use on the lac- tate carriers' gene expression and its association with aerobic training. So, considering the need to develop therapeutic strategies for the prevention or treatment of diabetes-related complications, and assuming that the use of DCA after endurance training can be helpful in improving the changes of lactate carriers' gene expression in the heart of diabetic patients, the need for further research in this field is felt.

\section{Materials and Methods}

The present study is experimental (ethical code: EE/97.24.3.70001/scu.ac.ir) and was conducted by a post-test with the control group. In this study, 64 male Wistar rats at 8 weeks of age and weighing $200 \pm 12$ g were bought from the Physiology Research Center, Ahvaz Jundishapur University of Medical Sciences, Iran. Rats were kept under the conditions of 12-12 (the even split of $12 \mathrm{~h}$ of light and 12 hours of darkness) at $22 \pm 2^{\circ} \mathrm{C}$ and $50 \%$ humidity, fed with water and rats special food.

After one week and familiarity with the laboratory environment, rats were matched based on the weight and were randomly divided into eight healthy control groups $(n=7)$, healthy control group + dichloroacetate $(n=7)$, healthy endurance training group $(n=7)$, healthy endurance training group $+\mathrm{di}-$ chloroacetate $(n=8)$, diabetes control group $(n=7)$, diabetes control group + dichloroacetate $(n=8)$, diabetes endurance training group $(n=8)$, diabetes endurance training group + dichloroacetate $(n=8)$. In the present study, to control PDK4 in the myocardium, daily intraperitoneal injection of DCA of $50 \mathrm{mg} / \mathrm{kg}$ body weight was used in normal saline solution [21]. After completing the identification protocol and following 12 hours of food deprivation, induction of diabetes was done by intraperitoneal injection of $50 \mathrm{mg} / \mathrm{kg}$ body weight of the streptozotocin solution (STZ) dissolved in citrate buffer $0.05 \mathrm{M}$ with $4.5 \mathrm{pH}$ [22]. The equivalent volume of citrate buffer $(\mathrm{M}=0.05, \mathrm{pH}=4.5)$ was also intraperitoneally injected to non-diabetic rats. 48 hours after injection, with a small injury by lancet on the tail vein, a drop of blood was placed on the glucometer strip and the strip was measured by the glucometer (Glucotrend 2, Roche Germany). Rats whose blood sugar was higher than $300 \mathrm{mg} / \mathrm{dl}$ were considered diabetic. To ensure that rats' blood sugar did not return, it was measured at the end of the training program [23].

DCA. DCA was injected to rats intraperitoneally at $50 \mathrm{mg} / \mathrm{kg}$ body weight in the form of 24 -hour 
intervals, dissolved in methyl cellulose $400 \mathrm{cP}$ and combined with calcium gluconate[24].

Endurance training protocol. The protocol was carried out for six weeks (five days/week). First, training groups were trained for seven days with a treadmill (model LE7800; Harvard Apparatus, France) at a speed of $15 \mathrm{~m} / \mathrm{min}$ for $20 \mathrm{~min}$. Then, the duration and speed were gradually increased over the course of six weeks, so that in the final week the speed reached $30 \mathrm{~m} / \mathrm{min}$ and the training time reached $50 \mathrm{~min} /$ day, which was equivalent to $75 \%$ of the maximum oxygen consumed. Electric shocks were performed on the rats to make them complete the training during the course of the experiment. Control groups were kept in cages untreated during the training period (Table 1) [25].

Seventy two hours after the last training session, 64 rats were anesthetized by intraperitoneal injection of ketamine ( $90 \mathrm{mg} / \mathrm{kg}$ body weight) and Xylazin (90 mg/kg body weight) and the myocardium was immediately removed and frozen in liquid nitrogen and transferred to $-80^{\circ} \mathrm{C}$ until used for further analysis.

$q R T-P C R$. Isol-RNA was used to extract mRNA. About 100 milligrams of myocardium tissue was ground and homogenized in one milliliter of Isol-RNA Lysis Reagent. Afterwards, the homogeneous product was centrifuged for $10 \mathrm{~min}$ at $12000 \mathrm{~g}$ and $4^{\circ} \mathrm{C}$, the supernatant was removed, and transferred to a new micro tube. In the next step, $200 \mu 1$ of chloroform was added to the separated supernatant and vigorously stirred for 15 sec. Then, micro tubes were re-centrifuged for $15 \mathrm{~min}$ at $12000 \mathrm{~g}$ and $4^{\circ} \mathrm{C}$. The aqueous phase was removed and $600 \mu \mathrm{l}$ of isopropyl alcohol was added and centrifuged at $12000 \mathrm{~g}$ to extract total RNA. The concentration of RNA and its purity were calculated by controlling the ratio of 260/280 $\mathrm{nm}$ OD where values between 1.8 to 2 were defined as acceptable purity. Synthesis of cDNA was carried out using Takara's cDNA synthesis kit, according to the manufacturer's instructions. Expression of the desired genes was measured
Table 1. Training protocol

\begin{tabular}{l|c|c|c|c|c|c|c}
\hline Week & $\begin{array}{c}11 \\
\text { acclima- } \\
\text { tization }\end{array}$ & 2 & 3 & 4 & 5 & 6 & 7 \\
\hline $\begin{array}{l}\text { Speed, } \\
\text { m/min } \\
\text { Time, } \\
\text { min }\end{array}$ & 15 & 20 & 24 & 24 & 28 & 28 & 30 \\
\hline
\end{tabular}

using real-time PCR and the results were quantified using the $2^{-\Delta \Delta C T}$ formula [26]. PCR reactions were performed using AMPLIQON RealQ Plus 2x Master Mix Green High ROX. 40 cycles were considered for each cycle of Real-Time PCR. And the temperatures of each cycle were set at $94^{\circ} \mathrm{C}$ for $20 \mathrm{sec}, 60-58^{\circ} \mathrm{C}$ for $30 \mathrm{sec}$ and $72^{\circ} \mathrm{C}$ for 30 sec. GAPDH was used as the reference gene to measure relative gene expression and melting curve analysis was performed to control the specificity of the product. The sequence of the primers used in the study is reported in Table 2.

Sequences for the forward and reverse primers used in qRT-PCR are given with their length in base pairs (bp), the Gene Bank Accession Number and name for the gene. Table 2 .

Statistical method. Shapiro-Wilk test was used to determine the normality of the data and Levine's test was used to test the homogeneity of the variances. Comparisons of variables between studied groups were carried out by using Two-Way analysis of variance (TWO-WAY ANOVA) test. When a significant effect was found, post-hoc Tukey's analysis was performed in order to pair wise comparison. All statistical analyses were done at a significance level of $P=0.05$.

\section{Result and Discussion}

The results of the study showed that $P D K 4$ gene expression in the diabetes group $(P=0.001)$, control + DCA group $(P=0.002)$, diabetes + DCA group ( $P=0.001)$, endurance training group $(P=0.022)$,

\section{Ta ble 2. Mouse-specific primer pairs used for quantitative RT-PCR}

\begin{tabular}{l|l|l|c}
\hline & \multicolumn{1}{c}{ Forward } & \multicolumn{1}{c}{ Reverse } & bp \\
\hline GAPDH & CATACTCAGCACCAGCATCACC & AAGTTCAACGGCACAGTCAAGG & 121 \\
MCT1 & TCAGTGTTGGATGTGGTGAATGG & TTGGACTAGAGGGTTAGGG & 102 \\
CD147 & TTCACCTTCCCCACACACTTC & TTCACCTTCCCCACACACTTC & 146 \\
PDK4 & TATCGACCCCAACTGCGATG & TGGATTGGTTGGCCTGGAAA & 243 \\
\hline
\end{tabular}


Ta b le 3. Physical characteristics of groups

\begin{tabular}{l|c|c|c|c|c|c|c|c}
\hline & CONT & $\begin{array}{c}\text { CONT+ } \\
\text { DCA }\end{array}$ & TRA & $\begin{array}{c}\text { TRA+ } \\
\text { DCA }\end{array}$ & DM & $\begin{array}{c}\text { DM+ } \\
\text { DCA }\end{array}$ & $\begin{array}{c}\text { DM+ } \\
\text { TRA }\end{array}$ & $\begin{array}{c}\text { DM+ } \\
\text { TRA+ } \\
\text { DCA }\end{array}$ \\
\hline $\begin{array}{l}\text { Starting } \\
\text { body } \\
\text { weight, g }\end{array}$ & $204 \pm 7$ & $207 \pm 8$ & $208 \pm 9$ & $211 \pm 5$ & $205 \pm 11$ & $209 \pm 6$ & $208 \pm 10$ & $209 \pm 7$ \\
$\begin{array}{l}\text { Terminal } \\
\text { body } \\
\text { weight, g }\end{array}$ & $223 \pm 14$ & $198 \pm 11$ & $188 \pm 10$ & $168 \pm 11$ & $216 \pm 14$ & $182 \pm 12$ & $163 \pm 12$ & $149 \pm 6$ \\
$\begin{array}{l}\text { Starting } \\
\text { glucose, } \\
\text { mg/dl }\end{array}$ & $104 \pm 11$ & $103 \pm 6$ & $107 \pm 8$ & $108 \pm 10$ & $440 \pm 81$ & $490 \pm 61$ & $412 \pm 77$ & $472 \pm 58$ \\
$\begin{array}{l}\text { Terminal } \\
\text { glucose, } \\
\text { mg/dl }\end{array}$ & $110 \pm 14$ & $111 \pm 6$ & $107 \pm 8$ & $108 \pm 10$ & $407 \pm 69$ & $328 \pm 52$ & $274 \pm 32$ & $178 \pm 28$ \\
\hline
\end{tabular}

diabetes + endurance training group $(P=0.009)$, endurance training + DCA group $(\mathrm{P}=0.027)$ and diabetes + endurance training + DCA group $(P=0.001)$ was higher compared to the control group. Also $P D K 4$ gene expression in the control + DCA group ( $P=0.003)$, endurance training group $(P=0.001)$, diabetes + endurance training group $(P=0.007)$ and endurance training + DCA group $(P=0.006)$ was lower compared to the control group (Fig. 1).

The MCT1 gene expression in the diabetes group was higher compared to the control group $(P=0.011)$ but in diabetes + DCA group $(P=0.011)$, endurance training group $(P=0.022)$, and diabetes + endurance training + DCA group $(P=0.001)$ was lower compared to the control group. Also the MCT1 gene expression in control + DCA group $(P=0.028)$, diabetes + DCA group $(P=0.003)$, endurance training group $(P=0.006)$, diabetes + endurance training group $(P=0.008)$, endurance training + DCA group $(P=0.033)$ and diabetes + endurance training + DCA group $(P=0.001)$ was lower compared to the diabetes group (Fig. 2).

The $C D 147$ gene expression in the diabetes group $(P=0.002)$ and diabetes + endurance training group ( $P=0.028$ ) was higher compared to the control group but in diabetes + DCA group $(P=0.001)$, endurance training group $(P=0.024)$ and diabetes + endurance training + DCA group $(P=0.018)$ was lower compared to the control group. Also the CD147 gene expression in control + DCA group

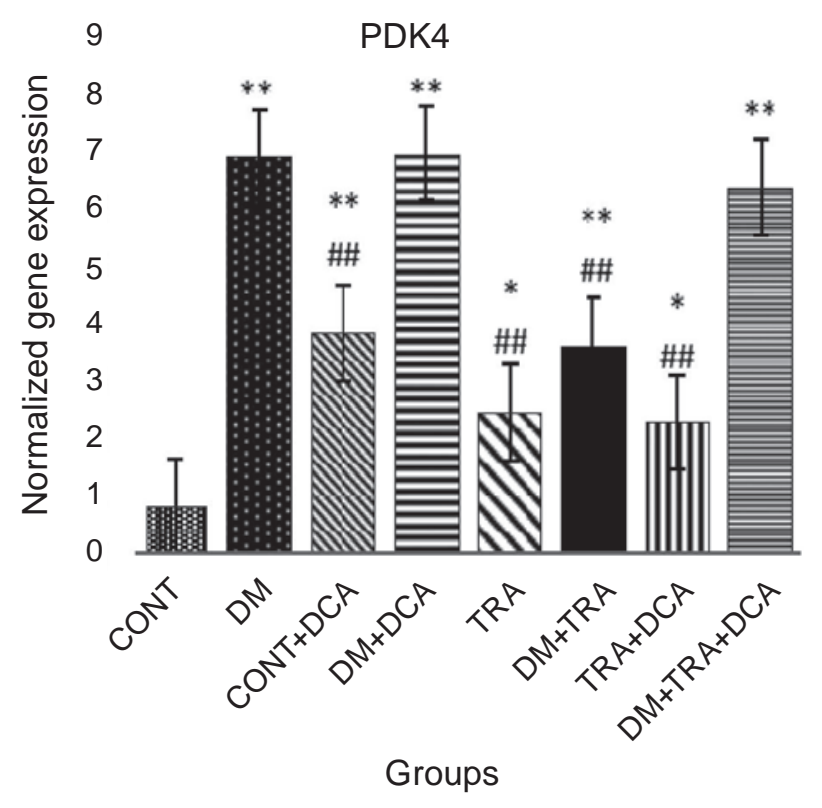

Fig. 1. The normalized gene expression of PDK4 in different groups. From left to right, control group (CONT) $(n=7)$; diabetes group $(D M)(n=7)$; control $+D C A$ group $(C O N T+D C A)(n=7)$; diabetes $+D C A$ group $(D M+D C A)(n=8)$; healthy group + training group (TRA) $(n=7)$; diabetes + training group $(D M+T R A)(n=8)$; healthy + training $+D C A$ group $(T R A+D C A)(n=8)$; diabetes + training + $D C A$ group $(D M+T R A+D C A)(n=8)$. Data are expressed as mean $\pm S D$. ${ }^{*} P<0.05$ and ${ }^{* *} P<0.01$ compared with the control group. ${ }^{\#} P<0.05$ and ${ }^{\#} P<0.01$ compared with the diabetic group 


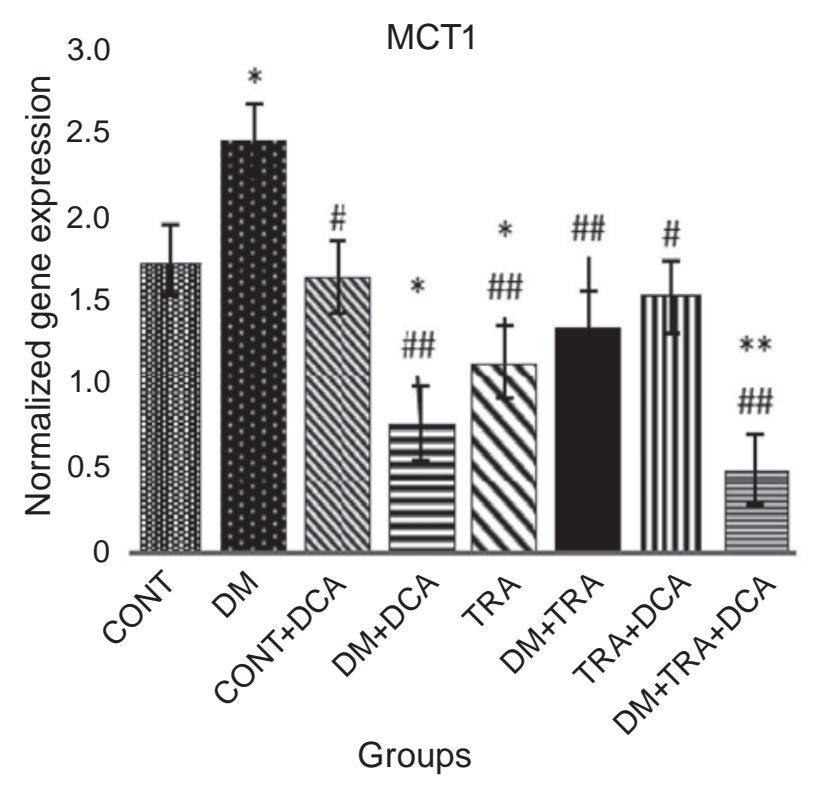

Fig. 2. The normalized gene expression of MCT1 in different groups. From left to right, control group (CONT) $(n=7)$; diabetes group $(D M)(n=7)$; control $+D C A$ group $(C O N T+D C A)(n=7)$; diabetes $+D C A$ group $(D M+D C A)(n=8)$; healthy group + training group (TRA) $(n=7)$; diabetes + training group $(D M+T R A)(n=8)$; healthy + training $+D C A$ group $(T R A+D C A)(n=8)$; diabetes + training + DCA group $(D M+T R A+D C A)(n=8)$. Data are expressed as mean $\pm S D$. $* P<0.05$ and $* * P<0.01$ compared with the control group. ${ }^{\#} P<0.05$ and ${ }^{\#} P<0.01$ compared with the diabetic group

$(P=0.008)$, diabetes + DCA group $(P=0.001)$, endurance training group $(P=0.004)$, diabetes + endurance training group $(P=0.036)$, endurance training + DCA group $(P=0.007)$ and diabetes + endurance training + DCA group $(P=0.001)$ was lower compared to the diabetes group (Fig. 3).

The present study was conducted to investigate the role of DCA (inhibition of PDK4) on expression of MCT1 and CD147 genes following endurance training. The most important results were that the expression of PDK4, MCT1, and CD147 genes increased in line with each other after endurance training and the expression of lactate carriers decreased both in the endurance training group + diabetes + DCA and in the diabetes group + DCA by inhibiting PDK4. In the present study, DCA has been used which is a halogenated carboxylic acid and which lead to increased PDC activity in animal [27], human muscle [28], and inhibition of PDK4, has been used. It performs this action competitively

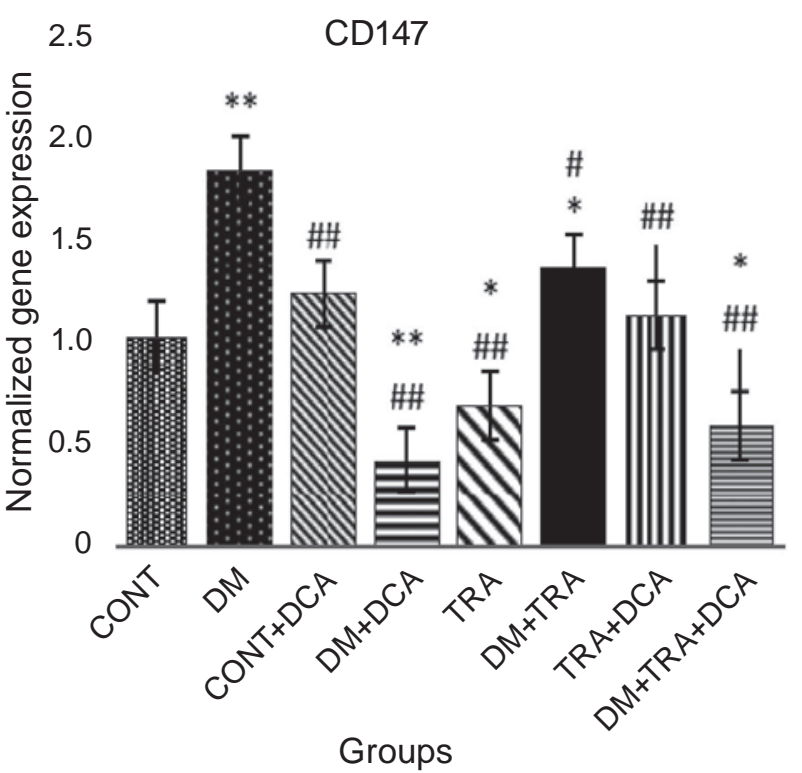

Fig. 3. The normalized gene expression of CD147 in different groups. From left to right, control group (CONT) $(n=7)$; diabetes group (DM) $(n=7)$; control $+D C A$ group $(C O N T+D C A)(n=7)$; diabetes $+D C A$ group $(D M+D C A)(n=8)$; healthy group + training group (TRA) $(n=7)$; diabetes + training group $(D M+T R A)(n=8)$; healthy + training + $D C A$ group $(T R A+D C A)(n=8)$; diabetes + training + DCA group $(D M+T R A+D C A)(n=8)$. Data are expressed as mean $\pm S D$. $* P<0.05$ and ${ }^{* *} P<$ 0.01 compared with the control group. ${ }^{\#} P<0.05$ and ${ }^{\#} P<0.01$ compared with the diabetic group

by inhibiting PDK2 and PDK4. DCA is known as a PDC activator [29]. Among the more important features of DCA was its ability to reduce blood glucose levels in diabetic rats, but there was no changes in the level of DCA-induced glucose in the non-diabetic animals [30]. DCA activates PDC in the mitochondria, followed by PDK4 leads to possible glucose control and increase of aerobic metabolic in mitochondria [19]. On the other hand, fatty acids and glucose are the main fuel in the heart of ordinary people (non-diabetic), while lactic acid, ketones, and amino acids play a minor role [31, 32]. The natural heart has a significant amount of metabolic flexibility that allows changing the type of fuel between fatty acid and carbohydrate oxidation depending on the workload of the heart, the energy consumed in proportion to the hormonal and nutritional activity and mode [31, 32]. The diabetic heart cannot fully utilize glucose due to its insulin resistance, and may therefore be forced to use almost exclusively fatty 
acids as an energy source [33]. The diabetic heart compared to non-diabetic heart increases the level of fatty matter or cardiac steatosis which results in oxidative stress and cardiac dysfunction [34]. However, it is not clear how the conditions of heart oxidation and metabolic flexibility change in diabetic patients. The study of Mizuno Y et al. shows that plasma levels of FFAs and glucose are higher in the heart and the amount of absorption of glucose, lactate and myocardial pyruvate is lower [35]. The results of this study were consistent with the current research. These findings suggest that the heart of diabetes uses some of the carbohydrates (glucose, lactate and pyruvate) as energy sources [17]. However, the pathophysiological mechanism of insulin resistance in diabetic patients of second type can be verified by several factors [36]. The availability of substrate and substrate competition between lactate, the free fatty acids and glucose for oxidation are proposed as two mechanisms for increasing insulin resistance and glucose intolerance [37]. The increase of lactate carriers' expression has been seen in diabetic patients (36) which is in line with the results of this study. On the other hand, the induction of diabetes in the present study increased the expression of MCT1, CD147 in the diabetic group and their mean was significantly higher than the control group. This result is confirmed by previous studies [38, 39]. It has also been shown in previous study that since the CD147 is needed for natural expression of MCTs, the studies that used the inhibition of CD147 expression have reported a clear reduction in the MCT1 expression and have confirmed that the CD147 is an auxiliary protein that is required for the natural expression of MCTs [40]. recent studies have suggested that the MCT1 is a carrier of lactate heteromeric, consisting of a monocarboxylated transducer unit and a CD147 subunit $[38,39]$. In this study, the DCA injection following endurance training reduced the expression of MCT1 and CD147 in the heart muscle. In the present study, the expression of CD147 in the heart muscle decreased in the diabetic groups by inhibiting PDK4 which could express this factor as a regulatory factor in the MCT1 expression in the heart muscle in response to exercise. Prescription of DCA leads to enhance mitochondrial mRNA genes that are as a part of metabolism adaptation induced by aerobic exercise. These adaptations are expressed in terms of enhancement of mitochondrial enzyme activity and fatty acid transfer protein (FAT/CD36), and glycogen concentration. These results indicate that repeated lactate accumulation in sports exercises in diabetic patients may decrease with mitochondrial adaptation due to exercise training. In the present study after DCA injection for 6 weeks and inhibition of PDK4 enzyme, the expression of PDK4 increased at the mRNA level which is a natural response to inhibit this key enzyme in the metabolism of aerobic energy [29]. However, Tomohiro Matsuhashi et al. showed in a study that the stable activation of PDH enzyme by DCA leads to excessive CoA production (increased oxidation in the Krebs cycle) and leads to histone acetylation which is one of the important epigenetic processes that regulates the expression of genes. Hence, DCH activation by DCA helps to change the heart proteins which at least partly form a molecular basis for the DCA anti-rebuilding effect. It can be aligned with the results of the present study to use DCA injection [29].

Conclusion. Overall, the results of this study showed that endurance training increased the expression of MCT1 and CD147 in the heart muscle of diabetic rats that was decreased with PDK4 inhibition by DCA, the MCT1 and CD147 gene expression declined to some extent. Since lactate is used in conjunction with other non-carbohydrate sources as an energy source rather than glucose in the diabetic heart of humans, but the high levels of lactate in diabetic patients can lead to a potentially life-threatening event due to repeated accumulation of lactate and it also increases oxidative stress in the heart tissue. Therefore, according to the results of this study, it can be expected that by inhibiting PDK4 through DCA injection, the repeated accumulation of lactate from sport exercises reduce in diabetic patients by mitochondrial adaptation. And subsequently reduced oxidative stress in the heart tissue of diabetic patients and increased cardiac efficiency.

Conflict of interest. Authors have completed the Unified Conflicts of Interest form at http://ukrbiochemjournal.org/wp-content/uploads/2018/12/ coi_disclosure.pdf and declare no conflict of interest.

Acknowledgments. The authors declare no conflicts of intrest. This study was extracted from the thesis for Ph.D. of Exercise Physiology at Shahid Chamran University of Ahvaz. We thank all the people who have collaborated with us in this research.

Authors' contributions. H.R. and A.H.H. were involved in study design, manuscript preparation, 
and editing. M.N was involved in animal experiments, preparing first draft and editing. M.R. and S.SH. were involved in animal experiments, qRTPCR, and ELISA assays. All authors read and approved the final manuscript.

\section{ЗМІНИ В ЕКСПРЕСІЇ ГЕНІВ ЛАКТАТНИХ ТРАНСПОРТЕРІВ (MCT1 ТА CD147) У СЕРЦЕВОМУ М'ЯЗІ ДІАБЕТИЧНИХ ЩУРІВ: ВПЛИВ ДИХЛОРАЦЕТАТУ ТА ТРЕНУВАНЬ НА ВИТРИВАЛІСТЬ}

\section{H. Rezaeinasab ${ }^{1 \bowtie}$, A. Habibi ${ }^{1}$, M. Nikbakht ${ }^{1}$, M. Rashno ${ }^{2,3}$, S. Shakerian ${ }^{1}$}

${ }^{1}$ Department of Exercise Physiology, Faculty of Sport Sciences, Shahid Chamran University of Ahvaz, Ahvaz, Iran; ${ }^{2}$ Department of Immunology, Faculty of Medicine, Ahvaz Jundishapur University of Medical Sciences, Ahvaz, Iran;

${ }^{3}$ Department of Cellular and Molecular Research Center, Ahvaz Jundishapur University of Medical Sciences, Ahvaz, Iran;

ॠe-mail: hamed.rezaei2020@gmail.com

Накопичення лактату може активувати мітохондріальний біогенез в серцевому м'язі. Метою цього дослідження було вивчити вплив інгібування піруватдегідрогенази кінази-4 (PDK4) і фізичних навантажень (тренування на витривалість) на експресію генів транспортерів лактату (MCT1 і CD147) в серцевому м'язі щурів зі стрептозотоциніндукованим діабетом. Експеримент проводили на 64 щурах-самцях лінії Wistar, які після індукування діабету було випадковим чином розділено на вісім груп. Тренування на витривалість виконували на біговій доріжці протягом 6 тижнів. Активність PDK4 в міокарді інгібували введенням дихлороцтової кислоти (DCA), 50 мг/кг маси тіла. Експресію генів вимірювали за допомогою ПЛР у реальному часі. Статистичну обробку даних здійснювали за допомогою двофакторного тесту ANOVA. Результати дослідження показали, що після тренувань на витривалість експресія генів MCT1, $P D K 4$ та $C D 147$ вірогідно зростала $(P<0,05)$, а за інгібування PDK4 у серцевому м'язі експресія генів MCT1 та CD147 статистично зменшувалась $(P<0,05)$ у групах: фізичне навантаження + діабет + DCA та діабет + DCA. Дійшли висновку, що накопичення лактату за фізичного наванта- ження у хворих на цукровий діабет зменшується завдяки мітохондріальній адаптації за ін'єкції DCA, що зумовлює зниження окислювального стресу і збільшує ефективність роботи серця.

К л ю ч о в і с лов а: експресія генів, піруватдегідрогенази кіназа-4 (PDK4), цукровий діабет, лактатні транспортери, тренування на витривалість, дихлороцтова кислота.

\section{Reference}

1. Kearney MT. Chronic heart failure and type 2 diabetes mellitus: The last battle? Diab Vasc Dis Res. 2015; 12(4): 226-227.

2. Liang Q, Satoru Kobayashi S. Mitochondrial quality control in the diabetic heart. $J$ Mol Cell Cardiol. 2016; 95: 57-69.

3. Cubbon RM, Woolston A, Adams B, Gale CP, Gilthorpe MS, Baxter PD, Kearney LC, Mercer B, Rajwani A, Batin PD, Kahn M, Sapsford RJ, Witte KK, Kearney MT. Prospective development and validation of a model to predict heart failure hospitalisation. Heart. 2014; 100(12): 923-929.

4. Keteyian SJ, Brawner CA, Savage PD, Ehrman JK, Schairer J, Divine G, Aldred H, Ophaug K, Ades PA. Peak aerobic capacity predicts prognosis in patients with coronary heart disease. Am Heart J. 2008; 156(2): 292300.

5. Mihl C, Dassen WRM, Kuipers H. Cardiac remodelling: concentric versus eccentric hypertrophy in strength and endurance athletes. Neth Heart J. 2008; 16(4): 129-133.

6. Brooks GA. Cell-cell and intracellular lactate shuttles. J Physiol. 2009; 587(Pt 23): 5591-5600.

7. Juel C. Current aspects of lactate exchange: lactate/ $\mathrm{H}^{+}$transport in human skeletal muscle. Eur J Appl Physiol. 2001; 86(1): 12-16.

8. Bishop D, Edge J, Thomas C, Mercier J. Effects of high-intensity training on muscle lactate transporters and postexercise recovery of muscle lactate and hydrogen ions in women. Am J Physiol Regul Integr Comp Physiol. 2008; 295(6): R1991-R1998.

9. Bonen A. The expression of lactate transporters (MCT1 and MCT4) in heart and muscle. Eur $J$ Appl Physiol. 2001; 86(1): 6-11.

10. Dubouchaud H, Butterfield GE, Wolfel EE, Bergman BC, Brooks GA. Endurance training, expression, and physiology of LDH, MCT1, and 
MCT4 in human skeletal muscle. Am J Physiol Endocrinol Metab. 2000; 278(4): E571-E579.

11. Bonen A, Tonouchi M, Miskovic D, Heddle C, Heikkila JJ, Halestrap AP. Isoform-specific regulation of the lactate transporters MCT1 and MCT4 by contractile activity. Am J Physiol Endocrinol Metab. 2000; 279(5): E1131-E1138.

12. De Heredia FP, Wood IS, Trayhurn P. Hypoxia stimulates lactate release and modulates monocarboxylate transporter (MCT1, MCT2, and MCT4) expression in human adipocytes. Pflugers Arch. 2010; 459(3): 509-518.

13. Kirk P, Wilson MC, Heddle C, Brown MH, Barclay AN, Halestrap AP. CD147 is tightly associated with lactate transporters MCT1 and MCT4 and facilitates their cell surface expression. EMBO J. 2000; 19(15): 3896-3904.

14. Benton CR, Yoshida Y, Lally J, Han XX, Hatta H, Bonen A. PGC-1alpha increases skeletal muscle lactate uptake by increasing the expression of MCT1 but not MCT2 or MCT4. Physiol Genomics. 2008; 35(1): 45-54.

15. Taegtmeyer H, Young ME, Lopaschu GD, Abel ED, Brunengraber H, Darley-Usmar V, Des Rosiers C, Gerszten R, Glatz JF, Griffin JL, Gropler RJ, Holzhuetter HG, Kizer JR, Lewandowski ED, Malloy CR, Neubauer S, Peterson LR, Portman MA, Recchia FA, Van Eyk JE, Wang TJ. Assessing Cardiac Metabolism: A Scientific Statement From the American Heart Association. Circ Res. 2016; 118(10): 1659-1701.

16. Boudina S, Abel ED.Diabetic cardiomyopathy revisited. Circulation. 2007; 115(25): 3213-3223.

17. Chong CR, Clarke K, Levelt E. Metabolic remodeling in diabetic cardiomyopathy. Cardiovasc Res. 2017; 113(4): 422-430.

18. Small L, Brandon AE, Quek LE, Krycer JR, James DE, Turner N, Cooney GJ. Acute activation of pyruvate dehydrogenase increases glucose oxidation in muscle without changing glucose uptake. Am J Physiol Endocrinol Metab. 2018; 315(2): E258-E266.

19. James MO, Jahn SC, Zhong G, Smeltz MG, Hu Z, Stacpoole PW. Therapeutic applications of dichloroacetate and the role of glutathione transferase zeta-1. Pharmacol Ther. 2017; 170: 166-180.

20. Tobina T, Yoshiok K, Hirata A, Mori S, Kiyonaga A, Tanaka H. Peroxisomal proliferatoractivated receptor gamma co-activator-1 alpha gene expression increases above the lactate threshold in human skeletal muscle. $J$ Sports Med Phys Fitness. 2011; 51(4): 683-688.

21. Sun XQ, Zhang R, Zhang HD, Yuan P, Wang XJ, Zhao QH, Wang L, Jiang R, Bogaard HJ, Jing ZC. Reversal of right ventricular remodeling by dichloroacetate is related to inhibition of mitochondria-dependent apoptosis. Hypertens Res. 2016; 39(5): 302-311.

22. Gajdosík A, Gajdosíková A, Stefek M, Navarová J, Hozová R. Streptozotocin-induced experimental diabetes in male Wistar rats. Gen Physiol Biophys. 1999; 18 Spec No: 54-62.

23. Thomas C, Perrey S, Lambert K, Hugon G, Mornet D, Mercier J. Monocarboxylate transporters, blood lactate removal after supramaximal exercise, and fatigue indexes in humans. J Appl Physiol. 2005; 98(3): 804-809.

24. Ferriero R, Iannuzzi C, Manco G, BrunettiPierri N. Differential inhibition of PDKs by phenylbutyrate and enhancement of pyruvate dehydrogenase complex activity by combination with dichloroacetate. J Inherit Metab Dis. 2015; 38(5): 895-904.

25. Sun L, Shen W, Liu Z, Guan S, Liu J, Ding S. Endurance exercise causes mitochondrial and oxidative stress in rat liver: effects of a combination of mitochondrial targeting nutrients. Life Sci. 2010; 86(1-2): 39-44.

26. Cook GA, Lavrentyev EN, Pham K, Park EA. Streptozotocin diabetes increases mRNA expression of ketogenic enzymes in the rat heart. Biochim Biophys Acta Gen Subj. 2017; 1861(2): 307-312.

27. Constantin-Teodosiu D. Regulation of muscle pyruvate dehydrogenase complex in insulin resistance: effects of exercise and dichloroacetate. Diabetes Metab J. 2013; 37(5): 301-314.

28. Mallinson JE, Constantin-Teodosiu D, Glaves PD, Marti EA, Davies WJ, Westwood FR, Sidaway JE, Greenhaff PL. Pharmacological activation of the pyruvate dehydrogenase complex reduces statin-mediated upregulation of FOXO gene targets and protects against statin myopathy in rodents. J Physiol. 2012; 590(24): 6389-6402.

29. Hoshino D, Tamura Y, Masuda H, Matsunaga Y, HattaH.Effects ofdecreased lactate accumulation after dichloroacetate administration on exercise training-induced mitochondrial adaptations in mouse skeletal muscle. Physiol Rep. 2015; 3(9): e12555. 
30. Lloyd S, Brocks C, Chatham JC. Differential modulation of glucose, lactate, and pyruvate oxidation by insulin and dichloroacetate in the rat heart. Am J Physiol Heart Circ Physiol. 2003; 285(1): H163-H172.

31. Stanley WC, Recchia FA, Lopaschuk GD. Myocardial substrate metabolism in the normal and failing heart. Physiol Rev. 2005; 85(3): 10931129.

32. Lopaschuk GD, Usshe JR, Folmes CDL, Jaswal JS, Stanley WC. Myocardial fatty acid metabolism in health and disease. Physiol Rev. 2010; 90(1): 207-258.

33. Fillmore N, Mori J, Lopaschuk GD. Mitochondrial fatty acid oxidation alterations in heart failure, ischaemic heart disease and diabetic cardiomyopathy. Br J Pharmacol. 2014; 171(8): 2080-2090.

34. Levelt E, Mahmod M, Piechnik SK, Ariga R, Francis JM, Rodgers CT, Clarke WT, Sabharwal N, Schneide JE, Karamitsos TD, Clarke K, Rider OJ, Neubauer S. Relationship between left ventricular structural and metabolic remodeling in type 2 diabetes. Diabetes. 2016; 65(1): 44-52.

35. Mizuno Y, Harada E, Nakagawa H, Morikawa Y, Shono M, Kugimiya F, Yoshimura M, Yasue H.
The diabetic heart utilizes ketone bodies as an energy source. Metabolism. 2017; 77: 65-72.

36. Bloomgarden ZT. Concepts of insulin resistance. Metab Syndr Relat Disord. 2005; 3(4): 284-293.

37. Petersen KF, Dufour S, Befroy D, Lehrke M, Hendler RE, Shulman GI. Reversal of nonalcoholic hepatic steatosis, hepatic insulin resistance, and hyperglycemia by moderate weight reduction in patients with type 2 diabetes. Diabetes. 2005; 54(3): 603-608.

38. Enoki T, Yoshida Y, Hatta H, Bonen A. Exercise training alleviates MCT1 and MCT4 reductions in heart and skeletal muscles of STZ-induced diabetic rats. J Appl Physiol. 2003; 94(6): 24332438.

39. Mondon CE, Jones IR, Azhar S, Hollenbeck CB, Reaven GM. Lactate production and pyruvate dehydrogenase activity in fat and skeletal muscle from diabetic rats. Diabetes. 1992; 41(12): 15471554.

40. Becker-Zimmermann K, Berger M, Berchtold P, Gries FA, Herberg L, Schwenen M. Treadmill training improves intravenous glucose tolerance and insulin sensitivity in fatty Zucker rats. Diabetologia. 1982; 22(6): 468-474. 